\title{
The influence of the organization structure changes on management and sports results in the Lech Poznan sports club between 2011 and 2014
}

\author{
Łukasz Karski \\ Department of Theory of Sport and Human Motorism, Faculty of Physical Education, \\ Gdansk University of Physical Education and Sport, Gdansk, Poland
}

\section{abstract}

Background: The increase in the competitiveness on the sports market forces elaboration of the proper organization structure in sports clubs. In 2011 Lech Poznan Club found itself in a situation which was inadequate to its ambition. The aim of this work is to present the influence of the implemented organization structure changes on the process of club management.

Material and methods: The subject of the research was the Lech Poznan club and its organization structure between 2011 and 2014. The applied research methods were the interview and the survey questionnaire.

Results: The introduction and the strategy realization, as well as the clear distribution of tasks were visible in the process of the changes in the organization structures. The success of those actions may be verified on the basis of the results of the end of season 2014/15

Conclusions: The conducted research shows that the Lech Poznan football club experienced transformation between 2011 and 2014. This transformation was adequate to the current trends of the sports club management, and it has permitted the club to win the Polish football championship.

Key words: management, organization structure, professionalization of sport, sports club.

\section{article details}

Article statistics: Word count: 4,167; Tables: 1; Figures: 17; References: 14

Received: January 2020; Accepted: May 2020; Published: December 2020

Full-text PDF: http://www.balticsportscience.com

Copyright @ Gdansk University of Physical Education and Sport, Poland

Indexation: Celdes, Clarivate Analytics Emerging Sources Citation Index (ESCl), CNKI Scholar (China National Knowledge Infrastructure), CNPIEC, De Gruyter - IBR (International Bibliography of Reviews of Scholarly Literature in the Humanities and Social Sciences), De Gruyter - IBZ (International Bibliography of Periodical Literature in the Humanities and Social Sciences), DOAJ, EBSCO - Central \& Eastern European Academic Source, EBSCO - SPORTDiscus, EBSCO Discovery Service, Google Scholar, Index Copernicus, J-Gate, Naviga (Softweco, Primo Central (ExLibris), ProQuest - Family Health, ProQuest - Health \& Medical Complete, ProQuest - Illustrata: Health Sciences, ProQuest - Nursing \& Allied Health Source, Summon (Serials Solutions/ProQuest, TDOne (TDNet), Ulrich's Periodicals Directory/ulrichsweb, WorldCat (OCLC)

Funding: This research received no specific grant from any funding agency in the public, commercial, or not-for-profit sectors.

Conflict of interests:

Corresponding author: Author has declared that no competing interest exists.

Łukasz Karski, Gdansk University of Physical Education and Sport - Sport and Tourism Management; Kazimierza Górskiego 1 80-336 Gdańsk Gdansk 80-336, Poland; e-mail: lukaszkarski1@gmail.com

Open Access License: This is an open access article distributed under the terms of the Creative Commons Attribution-Non-Commercial-NoDerivatives 4.0 International (https://creativecommons.org/licenses/by-nc-nd/4.0/), which permits use, distribution and reproduction in any medium, provided the original work is properly cited, the use is non-commercial and is otherwise in compliance with the license. 


\section{INTRODUCTION}

The changes which we can observe in football clubs of the highest level are the examples of the changes which are going to be visible in professional sport in the nearest future.

In the most popular disciplines, the process of professionalization and unification of the sports clubs functions can be observed for many years now. Nowadays, sport organizations operate under the market conditions; however, not every manager has the proper knowledge and experience to meet the challenge of "sport managing after 1989" [1]. Professional football in Europe has changed dramatically in the last two decades or so, largely due to the escalation of media rights deals. Many professional football clubs are now complex businesses, intrinsically concerned with financial matters [2, 3].

Club success in sports is a relative term. While some teams always try to win the league, others are happy with just staying in the competition. Before every season starts, sport experts analyze potential overachievers and underachievers, based on money spent, team's experience, and other quantitative and qualitative perceptions [4]. The clubs which have built their strong brands on the global sport market consider the ability of the expansion into the new sport market segments as their success. The football teams brand is part of the broader trend to market spaces [5]. Today sport is increasingly treated as merchandise and profitable investment. Contemporary sport contributes to the so called Lisbon goals realization, which consist of the acceleration of both the economic growth and the creation of new working places in the macroeconomic dimension, which is a kind of a tool for local and regional development [6].

Sport management is a compilation of the abilities connected to the expenses of planning, organizing, commissioning, controlling, leading and the rating in the context of the organization or its section, whose main product is connected to the sports market.

Professional football clubs (PFC) face a multitude of daily operations. They are involved in retailing, match day and ticketing activities, supply and distribution of players, branding leisurewear or first team kits sold through various channels, to name a few. To maintain profitability, expand into new markets, increase the value of the club, maximize media exposure, etc., its management has to address a lot of sport and non-sport challenges that engage with not one but a variety of supply chains [7].

The top management unit of football requires professional teams to continually improve the management standard, achieve organizational levels that will increase economic and financial opportunities, bring more discipline and rationality to football accounting, and achieve effective management and organizational skills through income generated by football. These demands from UEFA bring a systematic approach to organizing the existing sports facilities in the framework of today's business principles where information systems of different qualities in organizations are classified according to the organizational structure or the administrative level, functions, operations or activities, decision support, architectural structure, support areas [8, 9].

Organizational theorists have usually seen sports as an interesting field in which to illustrate organizational phenomena. This topic has been commonly discussed in the context of wider organizational studies, mainly related to organizational change, organizational performance and the structural configuration of organizations [10]. The sport club organization structure should reflect the structure of a producing company (division into the production and the functional departments). This commonly occurs in the sport and business departments in the organization's structure of professional sports clubs [11]. 
The importance of the individual and, most of all, those two-division departments in a sports club or another sport organization, including a sport association, depends on the orientation of the organization and its conditions. If the market circumstances have no influence on its functioning, a company (club) mainly focuses on the producing activity, and the functional division plays the service (technical) role. Then the financial department begins to implement a proper financial strategy, and the marketing activities and public relations become important, which arrange the relations with the sport clubs surroundings. Multi-faceted and complex institutional structures of professional sport require from the managers identification of the potential treats in relations with the surroundings of economy, politics and culture in the macro scale. Its proper definition permits arranging the processes, taking place in the sports club, and after the analysis, helps to prepare the accurate organizational structure.

The goal of this research is to present the process of the transformation in a sports club, mainly in its organizational structure and the tasks carried out by the key subjects, based on the example of men's football club. Another goal of this research is to identify the influence of the changes made in the particular divisions on the process of managing the club. The following research questions were posed:

1. What changes took place in the organization structure of the Lech Poznan club between 2011 and 2014?

2. What was the influence of the changes in the organizational structure in the club on the process of managing the club and its sports results?

\section{MATERIAL AND METHODS}

The subject of the research was the Lech Poznan club, specifically its organizational structure (2011-2014). The implemented research methods were an interview and a survey questionnaire. The material was collected in the spring of 2016 during conversations with the many years' employees and fans of the Lech Poznan club.

In the first part of the research, interviews with 10 present or past employees of the club (mainly in managerial positions) were conducted. The analyzed motives were the quantity of workers employed in particular permanent positions and the tasks of the chosen subjects.

The following were noted:

- analysis of strengths and weaknesses of the club in the aspect of competitiveness growth;

- identification of the factors which promote growth of competitiveness as a result of the internal conditions of functioning;

- identification of the barriers in the aspect of the competitiveness growth as a result of the external conditions (economic barriers, existing solution habits, methods of communication or the management procedures).

In the second part of the research, a survey was used to find opinions of 6 present club employees and 252 fans about the transformations which took place between 2011 and 2014.

\section{RESULTS}

After the 2010/11 season, the owner of the club Lech Poznan carried out a thorough analysis and, in spite of the permanent criticism from the club fans, he did not decide to proceed with a significant sale of the team players. Having the experience of managing 
a large company, he decided to implement a business model in the club. He chose to change the organization structure in order to make it adequate to the management model carried out in the leading European clubs. The structure of the Lech Poznan club in 2011 demanded immediate changes and order. It is shown in Fig. 1.

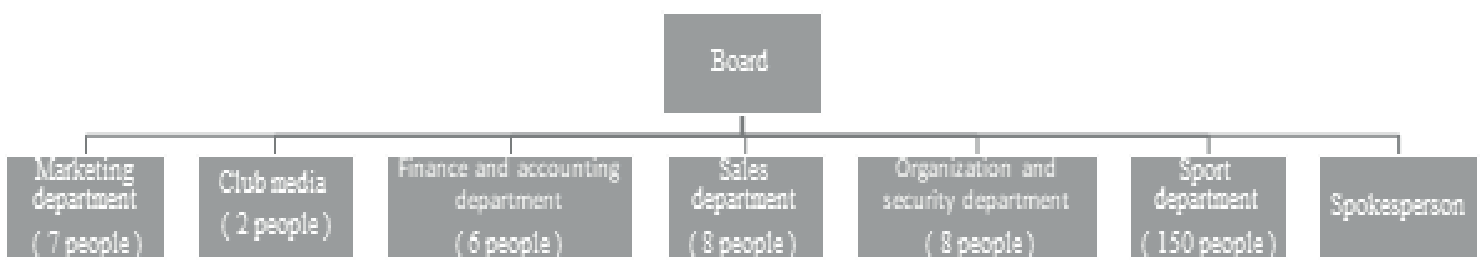

Fig. 1. Lech Poznan club organization structure at the end of 2011

In 2011, the first - as well as the most important change took place in the Lech structure. A meeting of the management of the club with the owners was organized. At this meeting a plan was presented that specified the stages of overcoming the crisis. The presented plan was not approved by the management, as a result of which the current president was replaced by a new one - Karol Klimczak. The club had the following main tasks to perform in the next few years: arranging the budget, implementing supervision over marketing and sales departments, building the relations between the particular divisions, creating the merchandise department.

Moreover, Piotr Rutkowski, a Maastricht University graduate, currently responsible for scouting, entered the managing board. He was responsible for the general matters connected with sport, and he took over the especially created for him position of the vicepresident of sport matters. The other newly created key position which has to be taken under consideration in the organization structure was the management's consultant of sport matters.

Afterwards, a decision was made to modify the lower levels of the club organization structure. The first department which underwent serious changes was the marketing division. The club was aware that without the proper promotion even the best product cannot be sold. The marketing department of the Lech Poznan club in the 2011 is presented in Fig. 2.

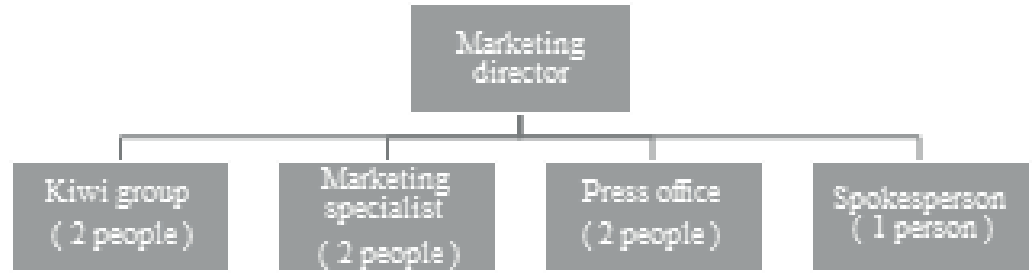

Fig. 2. Marketing department structure in 2011

At the beginning of 2012, the management decided to employ a new marketing director, who after a profound analysis, chose to terminate cooperation with the external company Kiwi Group. The new marketing director wanted to carry on with the marketing activities by the club and to plan them precisely, with the specified tasks to be fulfilled by everyone. One of the first decisions was to employ a person responsible for internet marketing and 
social media. The club media were included in the department were which consisted of 4 employees from this moment (and not two, as it was before). Their task was to arouse interest among the club fans and to create materials about all the club events. From this moment the Lech club was to be upfront and striving for dialogue with the fans. In 2014 the marketing department structure increased by 6 people, as presented in Fig. 3.

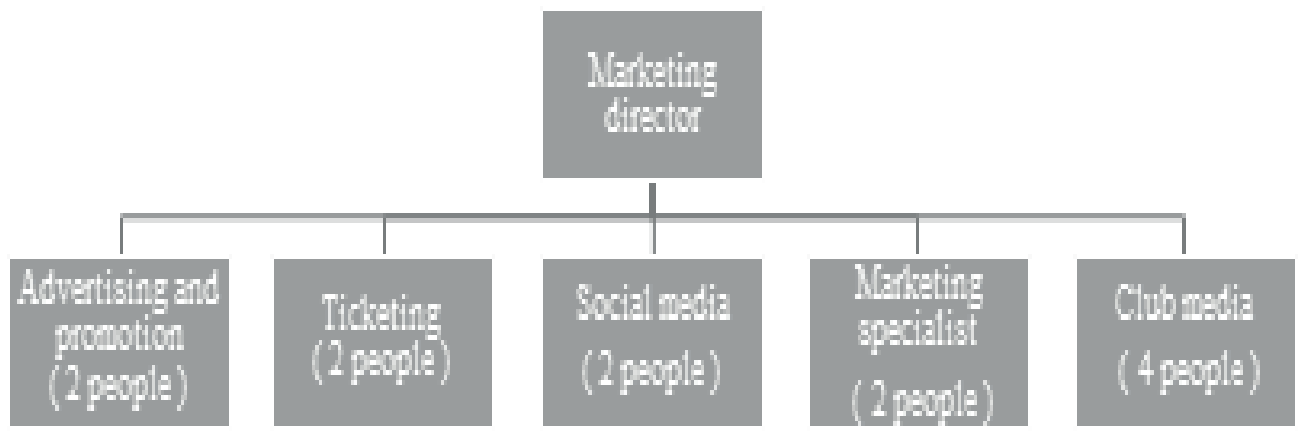

Fig. 3. Marketing department structure in 2014

During that time a new communication department ( 6 employees) was created, whose task was to cooperate directly with the marketing department. The press office and the spokesperson were included in the newly created communication department.

The financial and bookkeeping department was the crucial unit of the Lech structure. The essential change implemented since 2012 was to strengthen the department manager in the club structures, as he had become a financial director from that moment. The personal squad was increased by two people and after the carried out changes, the tasks of the accounting area remained the same.

The tasks connected to the widely considered controlling and reporting areas were carried out in a totally different way. To be precise, its subject was to implement the reporting obligations by the PZPN and UEFA (financial fair play) as well as the pressure reflected on the business effectiveness by the owner of the club. The transformations of the organization structure made it possible to achieve the goals.

Key changes took place in the analyzed period in the sales department. Near the end of 2011 it consisted of only three main departments: sales, sponsoring and the B2C sales. In September 2011 an agreement between Poznan City-POSiR and the Marcelin Management consortium was signed. According to this agreement, the consortium became the City Stadium Operator, and Lech achieved the possibility of organizing events and a chance for renting commercial rooms and halls to the external companies.

The hospitality department of the Lech Poznan club was one of the first among football clubs in Poland, and still today the Ekstraklasa clubs take example of its organizational structure. It is the evidence of the progress of the club management model and the longterm vision of the new club authorities. In order to use the potential of the stadium even more and to increase sales of the club offer, the stadium sightseeing tours and ice rink attractions were implemented.

What can be hailed as the unquestionable success is the acquisition of the sponsor of Lech's stadium. In June 2013 Inea, a telecommunication company, became one, and since then the stadium has been named the Inea Stadium. In addition, the agreement involved, 
among others, displaying the Inea logo in the stadium, marketing activities connected with this sponsorship and realization of additional mutual projects. The agreement was signed for 5 years, and its financial value remained confidential. Unofficial sources mention the amount of PLN 3.5m annually.

Simultaneously, the Club Board Management stated that the concluded contract with the city in 2011 had been generating too high costs, and they started to renegotiate it. The talks concluded with the signing of an agreement in June 2013. Since then, Lech Poznan has paid the rent of PLN 600 thousand per annum to the city, not PLN 3.1 million as previously. The above undertaking allowed spending the saved money on other purposes.

Within the implemented changes, there was also a decision to revolutionize the sales department. This change, as well as all the others, was well planned and preceded by specific research of the football market in Poland. A person with the experience of managing e-shop and visual merchandise was introduced. Therefore, professional structure was created which brought measurable financial profits.

Finally, after the whole process of the transformation the club structure almost doubled. The opening of the Academy in Wronki had a great influence on the numbers. The most important, however, was the quality change which took place in the club. The final organizational structure at the end of 2014 looked as follows.

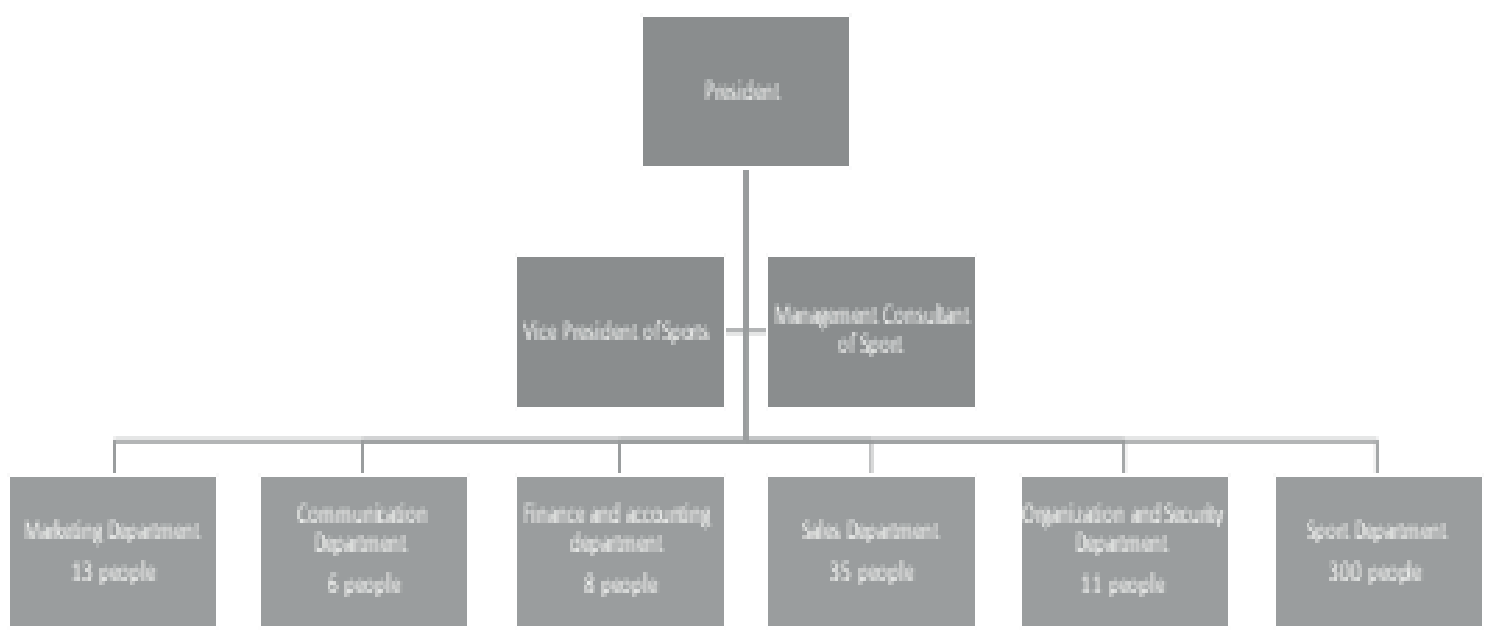

Fig. 4.Organization structure of the club Lech Poznan at the end of 2014

Since 2012 the top-level staff was obliged to present plans for the future. In the next stage, the plans were brought into discussion and profoundly analyzed. The club is a company based on the model of partnership; therefore, in 2013, a decision was made to implement a development strategy. The goals set in the strategy were not only to maintain the current position in Poland as well as in Europe, but also the constant development presented in the club's mission and vision. The general club strategy was based on a frequent growth of mainly two aspects, working in a strict symbiosis:

- sports department (sport result),

- marketing and sales department (financial result).

The SWOT analysis of the changes in the organizational structure is presented in Table 1. 
Table 1. The SWOT analysis of the changes in the organizational structure of the club Lech Poznan

\begin{tabular}{|c|c|}
\hline STRENGHTS & WEAKNESSES \\
\hline $\begin{array}{l}\text { - high qualifications of the employed staff, } \\
\text { - personnel with business acumen, } \\
\text { - high quality of services provided by the new staff, } \\
\text { - above average well-organized functioning of the club, } \\
\text { - good cooperation and relations between all } \\
\text { departments, } \\
\text { - the optimized costs of the club's operation, } \\
\text { - advanced IT solutions, } \\
\text { - the signing of a contract with the titular sponsor of the } \\
\text { stadium. }\end{array}$ & $\begin{array}{l}\text { - high rotation of staff, } \\
\text { - entering completely new areas of operation, } \\
\text { - small financial resources collected in the past. }\end{array}$ \\
\hline OPPORTUNITIES & THREATS \\
\hline $\begin{array}{l}\text { - well thought-over and planned vision of the club, } \\
\text { - innovative concept regarding marketing and sales, } \\
\text { - progress in the relationship with the city authorities, } \\
\text { - innovative actions to attract fans to the stadium, } \\
\text { - impact of the structural changes on the sports results, } \\
\text { - introducing new products on the market, } \\
\text { - variety and range of offered products, } \\
\text { - possibility of acquiring new partners and sponsors } \\
\text { thanks to new staff, } \\
\text { - possibility of managing the stadium. }\end{array}$ & $\begin{array}{l}\text { - uncertainty after the organizational changes in the } \\
\text { club, } \\
\text { - likelihood of highly qualified personnel leaving for the } \\
\text { competition, } \\
\text { - higher internal costs of employed staff, } \\
\text { - no guarantee that the changes in the organizational } \\
\text { structure are to impact the sports results positively. }\end{array}$ \\
\hline
\end{tabular}

After implementing the changes, season 2014/15 belonged to Lech in all aspects, and finally the club won the desired Polish championship. In the next season, 2015-2016, the club managed to be promoted to the group stage of the European League in which eventually it won the 3rd place scoring 5 points. Another achievement was winning with the Italian AFC Florentina, 2:1, while playing away. The club from Poznan won the financial classification (despite the lower income of the club by nearly a half compared to Legia Warsaw) and the sport effectiveness. They gave way to their rival from Warsaw only in the field of marketing and media. Winning the title of the Poland's Champion and carrying out the changes resulted in the growth of the clubs quality on the market. The income height (with the transfers included) and the current liquidity ratio of the club significantly increased in comparison with 2011 and 2014.

For the first time in three years Lech overtook Legia in the financial rank of the Ekstraklasa. The club's income with the transfers included, reached PLN 65.6 million, and the revenue was higher by nearly PLN 15 mln in comparison to 2011 (Fig. 5).

Fig. 5 The revePoznan club in

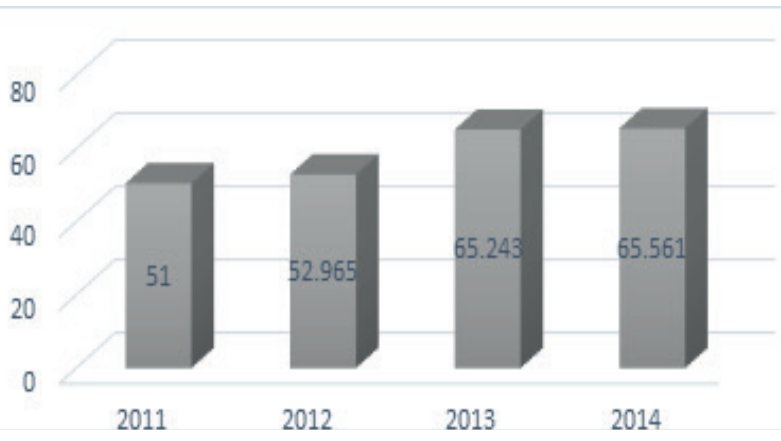

nue ratio of the Lech 2011-2014 (mln PLN)

At the same time, the club reached the highest revenue from transfers in season 2014-15 from all the clubs of the Polish Ekstraklasa and overtook the second in the table Legia Warsaw by more than PLN 7 mln (Fig. 6). 


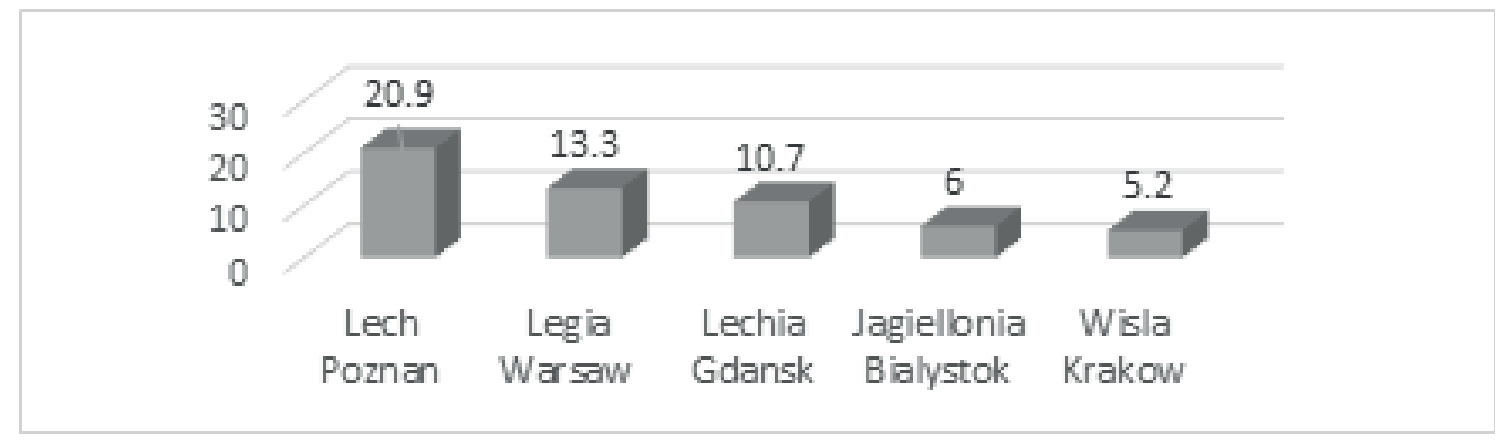

Fig.6. The highest revenues from transfers of the Polish Extraklasa clubs in season 2014-15 (mIn PLN)

It is worth pointing out that, besides the high revenues, Lech simultaneously recorded a significant increase in the financial liquidity comparing to 2011 (Fig. 7).

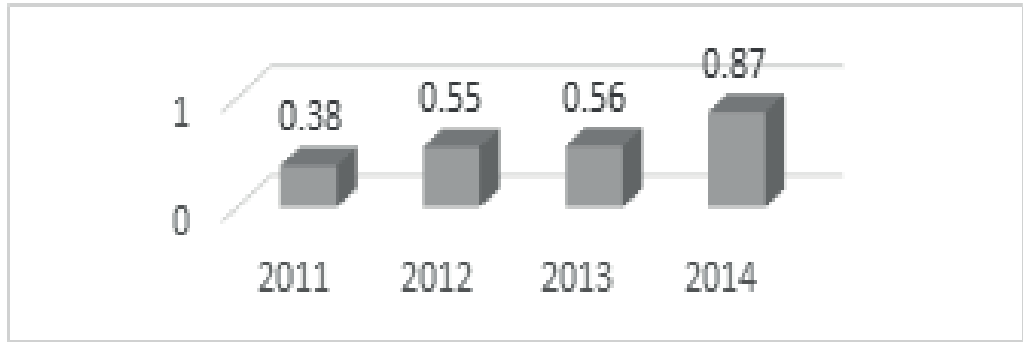

Fig.7. Lech Poznan club financial fluidity ratio in 2011-2014

The fans attendance in season 2014-15 contributed to the sports success. Lech gathered the largest total audience of all Ekstraklasa clubs (Fig. 8).

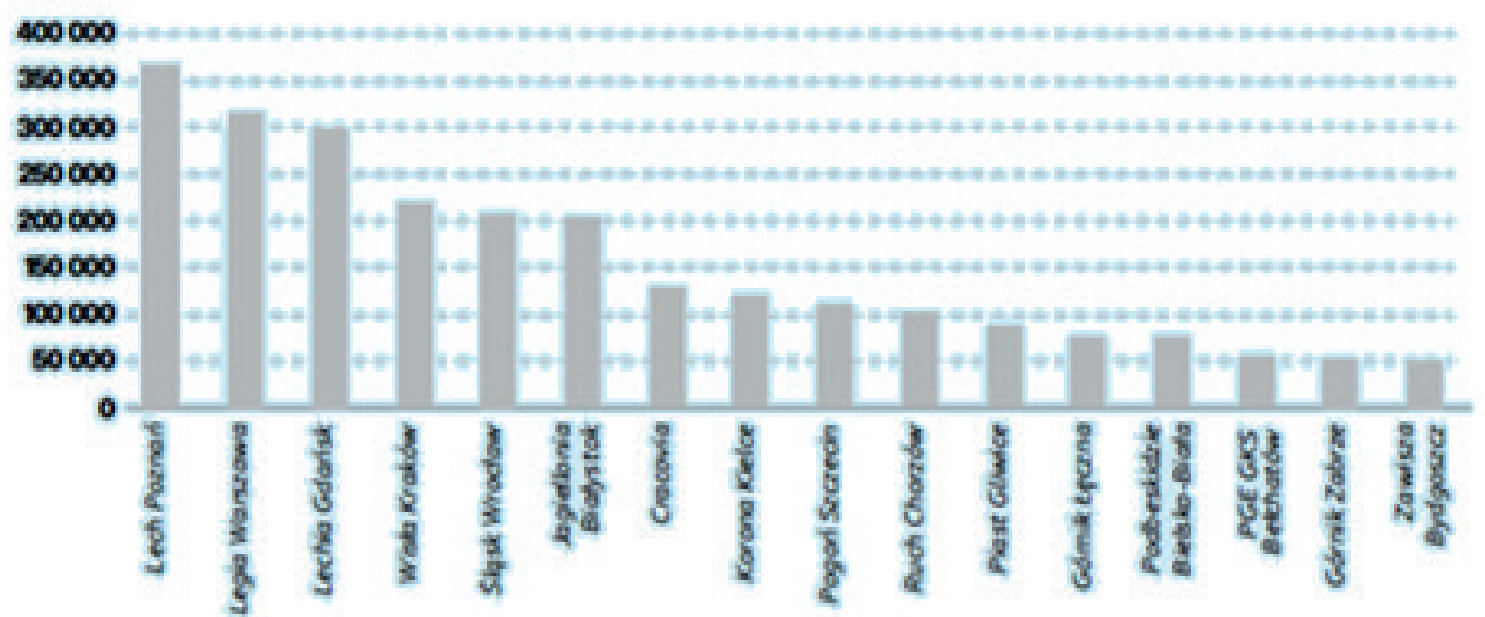

Fig. 8. The audience sum in season 2014-15

The attendance result was obtained thanks to the development of a special fix program by the club, whose aim was to attract fans to the stadium. From 2011 the following marketing campaigns were run:

- let's reach outside the stadium,

- regain credibility,

- the old and the new,

- image reconstruction,

- we listen and respond. 
All the above undertakings were met with positive feedback of the fans' community, thanks to which the attendance during matches played in Poznan between 2011 and 2015 significantly improved (Fig. 9).

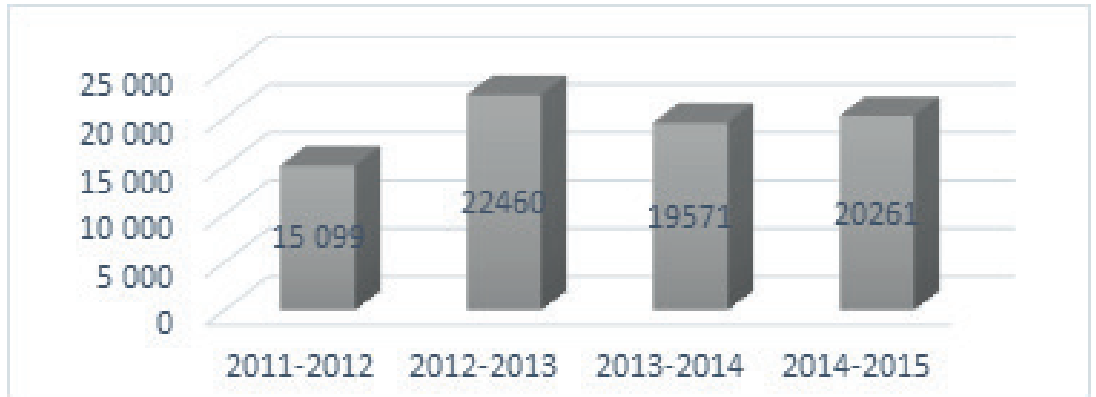

Fig. 9. Number of fans during matches of Lech Poznan club in 2011-2015

Proportionally to the increase in the number of fans at the stadium, there was an increase in the likes on the official Facebook profile by almost 200 thousand users between 2011 and 2014. Good results, attractive games, the presence of fans at the stadium and on social media was reflected in sales of the Club products. The best example was an official Club T-shirt which sold in the number of 7,000 in the season of 2014-2015, which was 2,500 more than in the previous season. The increase is shown in Fig. 10.

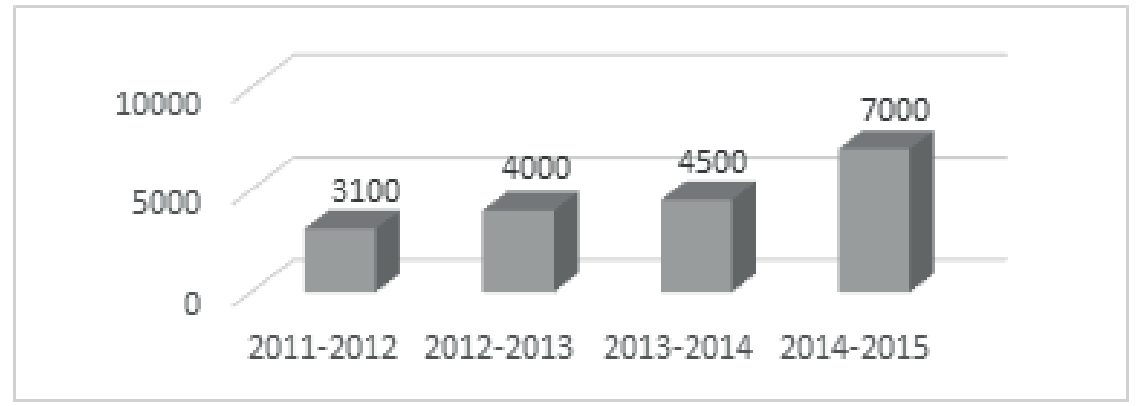

Fig. 10. Number of the official Lech Poznan club T-shirts sold in 2011-2015

After the analysis of the changes in the organization structure, the second stage of the research was carried out. In 2016 a questionnaire among the present employees of the club was conducted. The survey provided an answer to the question about the atmosphere in the club after its transformation. 6 employees from different departments of the club were asked to give their opinions on the actions taken by the president in 2012-2014 (in Polish academic scale 1-6, where 1 indicated unsatisfactory, 6 excellent). The results of the survey are presented in Fig. 11.

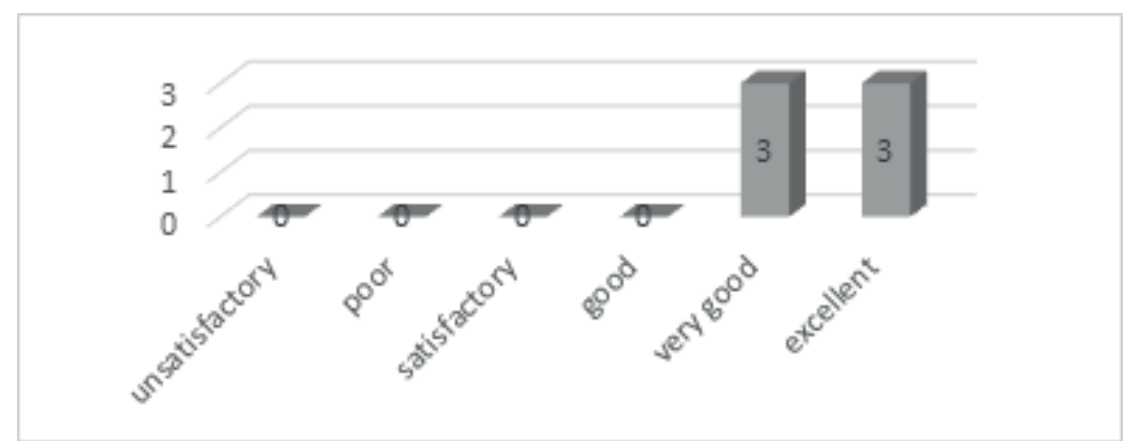


As it is shown in the analysis, the president Karol Klimczak was rated as very good or excellent by every respondent.

Another question concerned the opinion on the competence of the coworkers in one's department (Fig. 12).

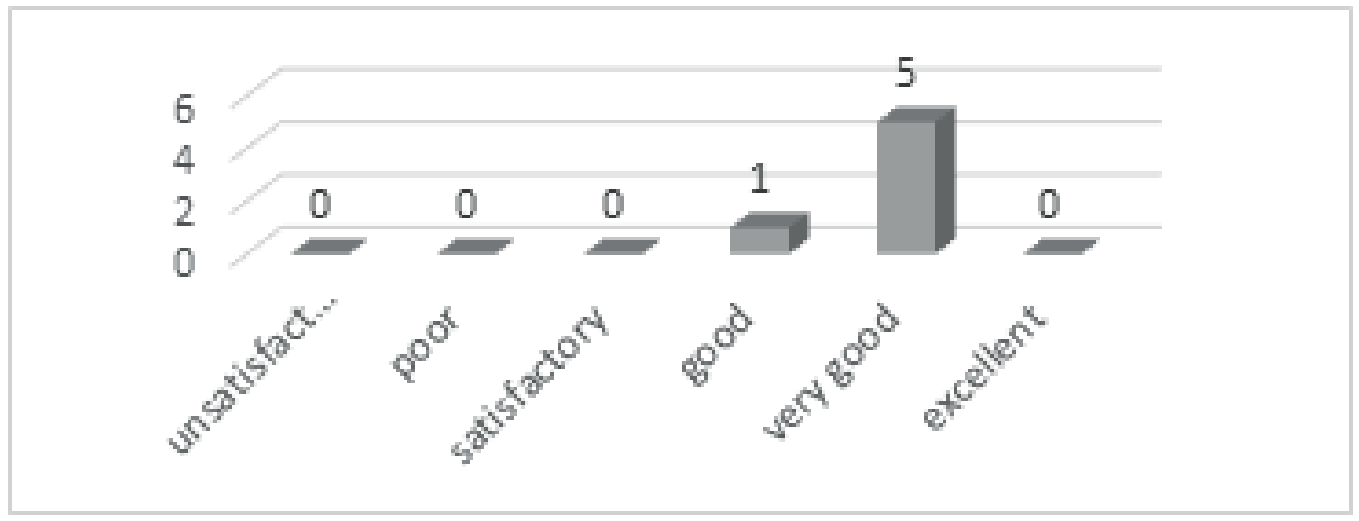

Fig. 12. Opinions on coworkers in the club Lech Poznan

The last question referred to the level of satisfaction with the present job and to the promotion prospects in the club (Fig. 13).

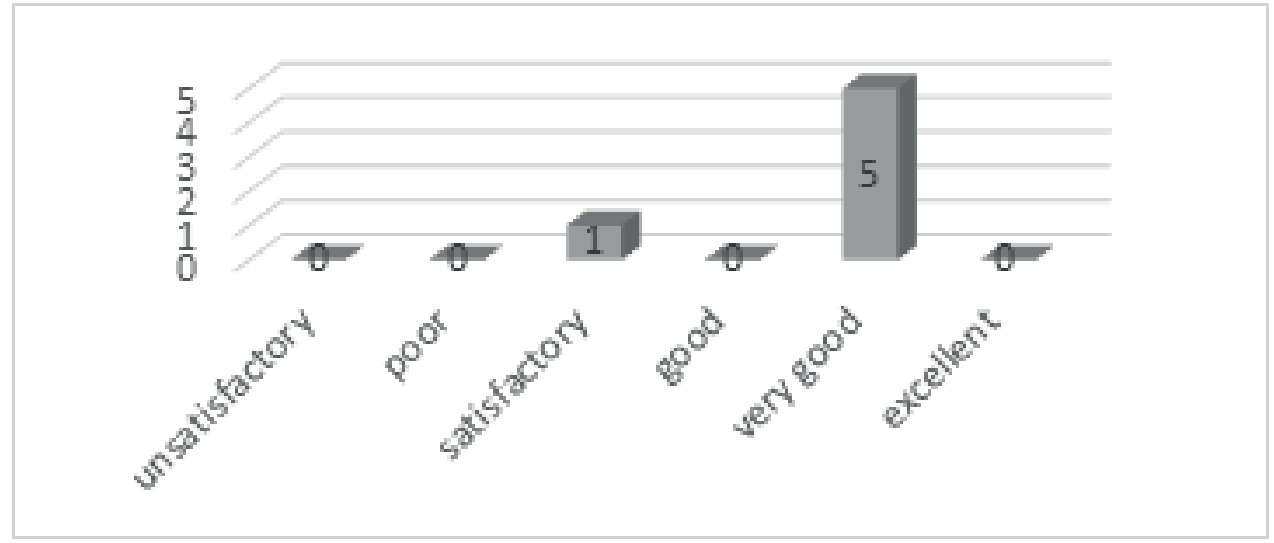

Fig.13. Opinions about job satisfaction and the promotion prospects for the employees of the club Lech Poznan

Creating a positive atmosphere in the company is a process which can take time and which requires cash outlays and proper attitudes from the employees as well as the employers. However, the challenge is worth taking because it creates investment which results in the creation of a well-coordinated team that understands well and pursues common goals. The Lech Poznan club stands here as the best example of measurable advantages for the whole company and management progress.

The second stage of the survey was based on the study that was conducted in April 2016. The respondents voluntarily agreed to participate, had their fan cards and attended a minimum of 50\% of Lech Poznan's home games in 2011-2014. The majority of them were men (Fig. 14) aged 30-35 (Fig. 15). 

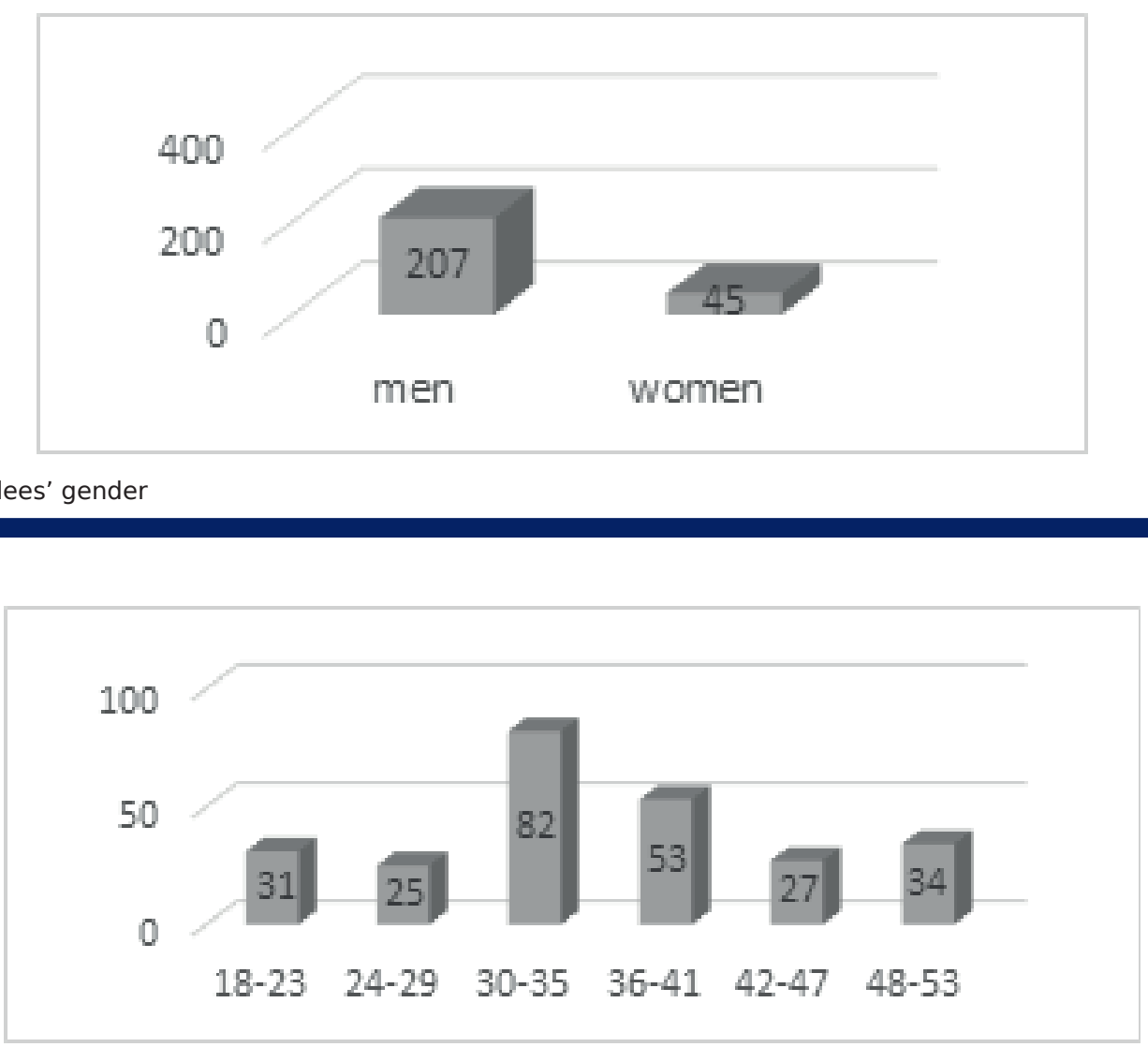

Fig.15. Attendees' age

The 252 fans were asked the same question like employees about their opinion of the actions taken by the president in 2012-2014 (Polish academic scale 1-6. where 1 indicated unsatisfactory, 6 excellent). The results of the survey are presented in Fig. 16

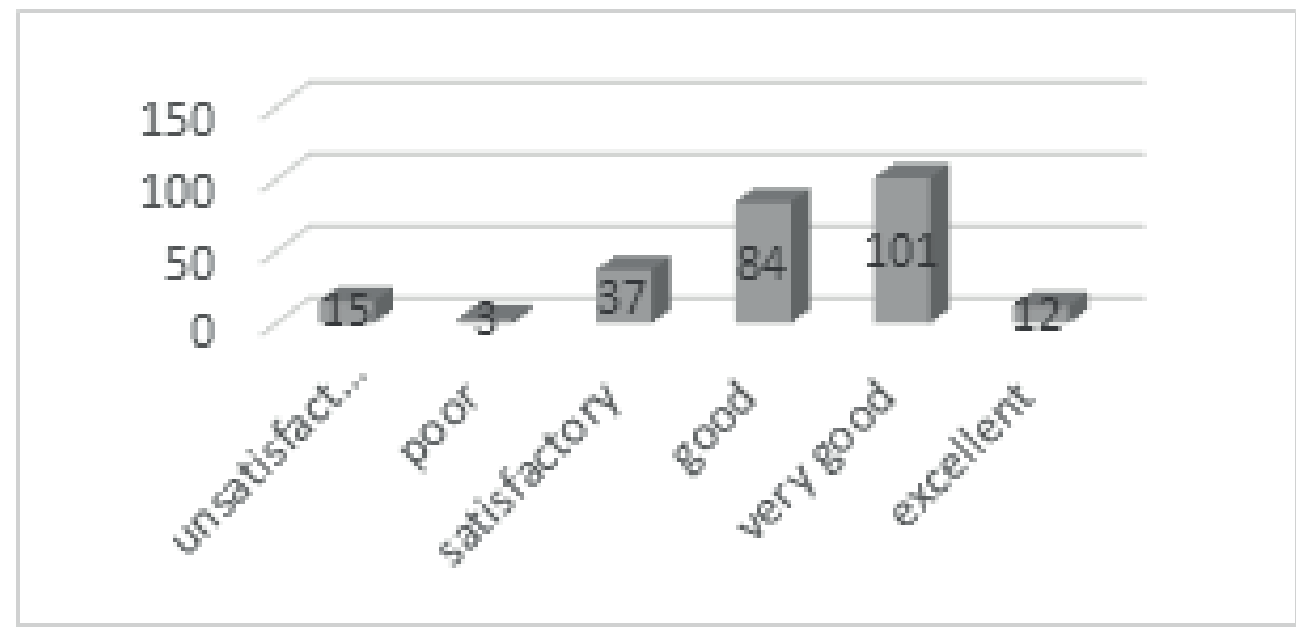

Fig.16. Opinions of the club Lech Poznan fans about the club's President

The second question about their opinions on the changes in Club KKS Lech Poznan in 2011-2014 gave results which are presented in Fig. 17. 


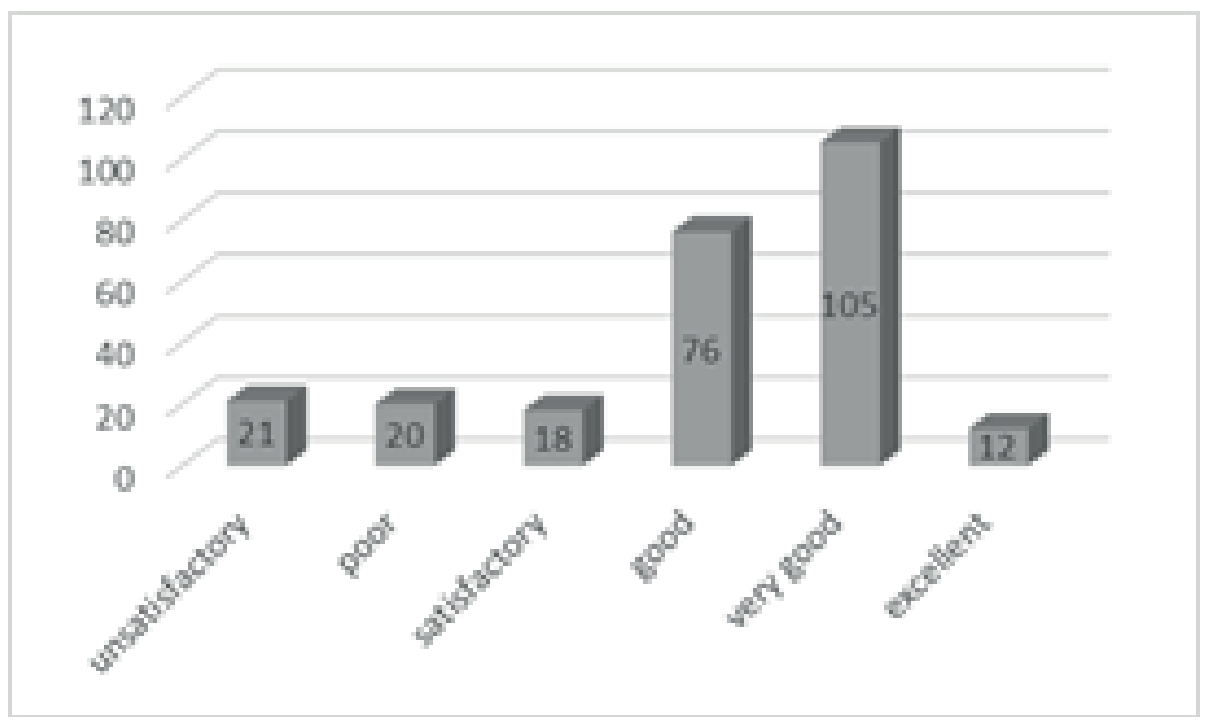

Fig.17. Opinions of Lech Poznan club's fans about changes in 2011-2014

As it can be seen from the second stage of the study both the activities of the Club's President and the implemented changes in 2011-2014 scored well or very well by the majority of fans. A fan is defined as a person who thinks, talks about and is knowledgeable about sports [12]. Every event (e.g. match) or information (e.g. about transfer) can trigger either very positive or negative emotions. This is an exclusive relationship between clientbrand, even with reference to the cult brands. The most important in the case discussed herein was that the transformations offered by the club were rated positively by the fans.

\section{DISCUSSION}

The decision about the changes in the particular structures were planned and profoundly thought over; therefore, the club is presently an organization which gathers specialists responsible for specific elements of activity and has high autonomy in their activities. It is very rare to carry out such a transformation in only a few years. In the club which was the subject of the research the main factor which reflected on the changes in the structures was appalling financial and sport results. Those results were such a mobilizing factor for the club authorities that in spite of the many difficulties and huge changes in the particular positions in the club, the set goal could be achieved. There was also a possibility of denying the thesis: sports clubs do not strive for the maximum profit [13].

Starting from 2012 the implemented division of duties was clear and understandable for everyone. The communication improved significantly and entirely new ideas appeared. From then on the club's management could effectively divide the tasks to every department. It was much easier than indicating the tasks individually to particular employees, as it was carried out even at the beginning of 2011.

There was a marked plan of the work for the nearest month, and afterwards every director passed the exact tasks to the members of his organization structure. Such construction of the structure also settled liability issues. By the end of the month every employee was obliged to prepare and present the report of his work, and the management - to present the general results of the whole department work. This system helped to get to know the weaker, less profitable sides of the club and to take them under higher consideration. It gave the immediate possibility to implement changes into the organization structure and to carry out the proper recruitment for a specific position. Introducing professionals 
with experience in management enabled dividing particular duties among workers of the lower levels of the structure.

After the transformation a questionnaire was carried out. It provided an answer to the question about the atmosphere in the club after the changes. The quality of the relations between people in the organization depends on the manager's personality and his style of managing. The fact that the development of sport organizations (from the economic and social aspects) is conditioned by the level of managers' education and their innovative knowledge can be established if we take into account other study results by a number of authors working in the same field [14].

\section{CONCLUSIONS}

Nowadays sport clubs more often than ever face the challenge of finding the most effective solution for the sport and commercial success. The carried out research shows that the football club Lech Poznan underwent transformation in last years which is adequate to the modern trends in the sport club management.

In the analysis of the achieved results there were no points which could have a negative influence on the club's functioning. During the process of the research with the club employees a positive energy and a huge commitment to work was visible. At the same time, the club employees have great autonomy in their work, their tasks depend on the actual set goal and their work is dedicated to this goal. Success of those actions is verified based on the results of the end of season 2014-15. It showed the validity of the changes taking place in 2011-14.

To succeed in sports and financial areas, one should constantly strive to develop and maintain an optimal organizational structure. In subsequent years, Lech Poznan was unable to retain experienced managers and be content with worked out assumptions. Currently, a football club must be a well-functioning enterprise, and the lack of continuation of the adopted strategy after 2015 has resulted in failures in the sports arena in the following years.

\section{REFERENCES}

[1] Jedel J, Kędzior M, Kopczyk R, Lubomańska-Palarczyk M, Moska W, Schwarz M, Zawadzki J. Rynek sportu. Zakres problematyki. [Sport Market. Range of Issues] Gdańsk: Wydawnictwo Uczelniane Akademii Wychowania Fizycznego i Sportu; 2015. Polish.

[2] Howieson B, Morrow S. The new business of football: a study of current and aspirant football club managers. J Sport Management. 2014;28:515-528. https://doi.org/10.1123/jsm.2013-0134

[3] Krisztina A, Zsolt H. New business strategies of football clubs. Scientific Papers. 2015;1-2;67-74. https://doi. org/10.19041/APSTRACT/2015/1-2/13

[4] Georgievski B, Labadze L, Aboelsoud ME. Comparative advantage as a success factor in football clubs: Evidence from the English Premier League (EPL). J Human Sport Exerc. 2018;14(2):292-314. https://doi.org/10.14198/ jhse.2019.142.04

[5] Enderson T, Millington S. 'This is Our City’: Branding football and local embeddedness. Global Networks. 2008;8:172193. https://doi.org/10.1111/j.1471-0374.2008.00190.x

[6] Cieslikowski K, Grzeganek-Więcek B, Hadzik A, Kantyka J. Anatomia organizacji sportowych i turystycznych. [Anatomy of sporting and tourist organizations]. Katowice: AWF. 2014. Polish.

[7] Egilsson B. Supply chain management practice in professional football clubs: a european perspective. SIG Managing sport General Track. 2017. https://doi.org/10.4324/9781351262804-26

[8] Samur S. Organization design in football management process. J Hum Mov Sport Sci. 2018;6(2):38-46. https://doi. org/10.13189/saj.2018.060203

[9] Moisescu P, Moisescu F. Sports organization management: between constraints and objectives. Procedia - Social and Behavioral Sciences. 2013;81:95-99. https://doi.org/10.1016/j.sbspro.2013.06.394

[10] Gomez S, Opazo M, Marti C. Structural characteristics of sport organizations: main trends in the academic discussion. SSRN Electronic Journal. 2008;730. https://doi.org/10.2139/ssrn.1116226

[11] Sznajder A. Marketing sportu [Sport Marketing] Warszawa: Polskie Wydawnictwo Ekonomiczne; 2008. Polish. 
Karski L.

Organization structure changes vs. management and sports results in the Lech Poznan sports club

Balt J Health Phys Act. 2020; Suppl (1): 19-32

[12] Norris I, Wann D, Zapalac R. Sport fan maximizing: Following the best team or being the best fan? J Consum Marketing 2014;32(3):157-166. https://doi.org/10.1108/JCM-02-2014-0856

[13] Masala A, Radjo I, Talovic M. The effect of sports managers education on business success in basketball, volleyball and handball. Homo Sporticus Issue. 2013;2:19-20.

[14] Siegfried N. Goals of sports clubs. Eur J Sport Society. 2008;5(2):121-141, hhttps://doi.org/10.1080/16138171.200 8.11687815

Cite this article as:

Karski L.

The influence of the organization structure changes on management and sports results in the Lech Poznan sports club between 2011 and 2014

Balt J Health Phys Act. 2020;Suppl(1):19-32

doi: 10.29359/BJHPA.2020.Suppl.1.03 